\title{
Aluminium Phosphide Poisoning
}

\author{
Babak Mostafazadeh \\ Shahid Beheshti University of Medical Sciences, \\ Iran
}

\section{Introduction}

Acute aluminium phosphide poisoning is an extremely lethal poisoning. Ingestion is usually suicidal in intent, uncommonly accidental and rarely homicidal. Unfortunately the absence of a specific antidote results in very high mortality and the key to treatment lies in rapid decontamination and institution of resuscitative measures.Aluminium phosphide is a solid fumigant which has been in extensive use since the 1940s. It has rapidly become one of the most commonly used grain fumigants because of its properties which are considered to be near ideal; it is toxic to all stages of insects, highly potent, does not affect seed viability, is free from toxic residues and leaves little residue on food grains(Hackenberg, 1972).

They are formulated as compressed discs, tablets or pellets that commonly weigh $3 \mathrm{~g}$ and contain variable amounts of a single phosphide in combination with other substances such as ammonium carbonate. Tablets are dark brown or grayish in colour. It is freely available in the markets with the major virtues of being cheap and not leaving toxic residues. The specified fatal dose in human is $0.15-0.5 \mathrm{gm}$. Phosphides are used widely to protect grain held in stores, the holds of ships and in wagons transporting it by rail and are admixed with the grain at a predetermined rate as it is put into storage. Moisture in the air between the grains mixes with phosphide and release phosphine (hydrogen phosphide, phosphorus trihydride, $\mathrm{PH} 3$ ) which is the active pesticide. After contact with an acid, phosphine is released even more vigorous. Two kinds of acute poisoning with these substances are reported: indirect inhalation of the phosphine generated during their approved use or direct ingestion of the salts.

Pure phosphine is colorless and odorless up to toxic concentrations (200 ppm), a view accepted by the International Programme on Chemical Safety and others (Pepelko, et al, 2004; Chaudhry, 1997; IPCS, 1988; Dumas \& Bond, 1974), it has an odor of garlicky or decaying fish due to the presence of substituted phosphines and diphosphines.If the former view is accepted the smell emanating from phosphide poisoned patients is probably due to contaminants in the pesticide formulations and not phosphine itself. It has been suggested that these volatile contaminants may be alkylphosphines (Fluck, 1976). For "phosphine" liberated from one pesticidal formulation of aluminium phosphide, the odor threshold was 0.01-0.02 ppm, ten times lower than that derived from the technical salt alone (Fluck, 1976).The usefulness of phosphide pesticides is now threatened by the development of resistance to them.

\section{Methods}

To complete this review, the terms aluminum and aluminum phosphide and phosphine were searched using the TUMS (Tehran University of Medical Science) digital library, 
Medline, pubmed and Google Scholar databases. All applicable articles in English were attained. Many isolated case reports and small case series do not appear in the citation list. The ability to highlight important aspects is the only criterion for inclusion in this review.

The criteria used in the current review include below criteria: Articles were selected based on the impact of lifestyle, stress, and/or environmental factor/s predisposing aluminium phosphide poisoning exposure. Criteria for selection of the literature used included yes-no responses to the appropriateness of methodology; adequacy of subject numbers; specificity of sex and/or age of subjects, and statistically significant response rates to survey questionnaires. The time frame used was principally 1990-2011 inclusive, although articles of extreme importance from earlier decades were used where appropriate. A multifactorial overview of the factors eschewed concerning aluminium phosphide poisoning exposure was elucidated. It was supposed that collective articles detailing known factors of usage were not necessarily correlated with functionality and health. Collection of materials for the review started with the published literature or easily available academic research.

\section{Epidemiology}

Annually about 300000 deaths are reported by pesticides poisoning worldwide (Eddleston \& Phillips, 2004). The most reports of acute pesticide poisoning only based on hospital records admission and as a result absolutely reflect a small part of the real incidence. In Asian region about 25 million agricultural workers suffer from an episode of poisoning each year(Jeyaratnam, 1990). In "phosphine" poisonings reported from Germany, 28\% were planned and mostly by eating, whereas the majority of the $65 \%$ accidental exposures were by inhalation (Lauterbach, et al, 2005). A report has also been publishedfrom the United Kingdom where the majority of 93 aluminum phosphide exposures were accidental and concerned inhalation of phosphine in agricultural locations(Bogle, 2006).

\section{Ingestion of phosphides}

Phosphide ingestion is a particular problem in rural India, the origin of most of the data on this topic (Rastogi, et al, 1990; Chugh, et al, 1991, 1998; Singh, 1996; Gargi, et al, 2006). The aluminium salt is most commonly involved. Indeed, in a prospective study of 559 acute poisonings admitted over 14 months to a single hospital in Harayana-Rohtak, India, no fewer than 379 (68\%) involved aluminium phosphide (Siwach \& Gupta, 1995). Similarly, reports to the National Poisons Centre in Delhi indicate that aluminium phosphide is the pesticide most commonly ingested by children (Gupta, et al, 2003).

Much smaller numbers or only sporadic cases of phosphide poisoning have been reported from the remainder of the world, including Australia (Nocera, et al, 2000), Denmark (Andersen, et al, 1996), France (Anger, et al, 2000), Germany (Alter, et al, 2001), Greece (Frangides \& Pneumatikos, 2002), Iran (Pajoumand, et al, 2002), Jordan (Abder-Rahman, et al, 2000), Morocco (Idali, et al, 2005; Hajouji, et al, 2006; Akkaoui, et al, 2007), Nepal (Lohani, et al, 2000), Sri Lanka (Roberts, et al, 2006), Turkey (Bayazit, et al, 2000), the United Kingdom (Stewart, et al, 2003; Lawler \& Thomas, 2007), Canada, the United States (Broderick \& Birnbaum, 2002, Ragone, et al, 2002), the former USSR (Rimalis \& Bochkarnikov, 1978), and Yugoslavia (Curcic \& Dadasovic, 2001). A single death from ingestion of a falsely labeled rodenticide bait has been reported (Azoury \& Levin, 1998). Phosphide rodenticides were responsible for nine out of 349 deaths in 35,580 poisoning admissions to Loghman Hakim hospital poison center in Tehran (Pajoumand, et al, 2002). 


\section{Occupational and environmental phosphine exposure}

Occupational exposures to phosphine are uncommon and rarely severe (Sudakin, 2005) but accidental inhalation is a particular risk to those in close proximity to grain that has had a metal phosphide mixed in with it. Recurring locations include ships holds (Gregorakos, et al, 2002, Hansen \& Pedersen, 2001, Vohra, et al, 2006), rail wagons (Perotta, et al 1994, Vohra, et al, 2006), grain elevators (Abder-Rahman, et al, 2000), grain stores (Brautbar \& Howard, 2002, Misra, et al, 1988), and even stores in homes (Abder-Rahman, et al, 2000). Potentially lethal concentrations of the gas may develop in the head-spaces of unventilated or poorly ventilated storage containers and domestic premises (Memis, et al, 2007).

Phosphine may be released during the illicit manufacture of methamphetamine (Burgess, 2001, Willers-Russo, 1999); deaths have resulted (Willers-Russo, 1999). In another incident, a packet of aluminium phosphide in a container from abroad burst open and the sweepings placed in water causing immediate fizzing and liberation of phosphine (Kamanyire \& Murray, 2003). Close proximity to a source of phosphine is not required to be at risk of toxicity as phosphine gas can travel some distance as it is heavier than air (vapor density 1.2:1). Many years ago 12 individuals in a house adjacent to a warehouse used to store aluminium phosphide developed vomiting and one died. The illnesses were attributed to phosphine (Glass, 1959). More recently exposures have been alleged after use of metal phosphides to control pests in adjacent buildings (Popp, 2002).

\section{Mechanism of action}

The exact mechanism of action of aluminum phosphide poisoning is still unknown, however an initial survey on different animals showed non-competitive cytochrome oxidase binding by phosphine, changes valences of haeme component of haemoglobin.Other than later articles, distinguished significant inhibition of catalase goes to hydrogen peroxide agglomeration (Price, et al, 1982), Extra-mitochondrial release of hydrogen peroxide and oxygen free radicals (Bolter \& Chertuka, 1989), leading to lipid peroxidation and protein denaturation of cell membrane are reported in more recent studies (Chug, et al, 1969). Also, aluminum and phosphine (Potter, et al, 1993; Al-Azzawi, et al, 1990), inhibit cholinesterases activity . Al-Azzawi showed in vitro exposure to phosphine lead to reducing human serum cholinesterase activity; in addition he showed the amount of the inhibition is related to the duration and concentration of phosphine (Al-Azzawi, et al, 1990). On the other hand, other studies declared there is no erythrocyte cholinesterase activity reduction in humans after accidental phosphine inhalation (Heyndrickx, et al, 1976; Wilson, et al, 1980).

\section{Toxicokinetics}

Phosphine must be quickly and easily absorbed because of the short interval between ingestion and the appearance of systemic toxicity features. Noticeably, phosphides possibly absorbed as microscopic particles of unhydrolysed salt (Stewart, et al, 2003, Chan, et al, 1983) and permanently, in vitro, interact with free hemoglobin and hemoglobin in intact erythrocytes (rat and human) to produce a hemichrome (a methemoglobin derivative resulting from distorted protein conformation) (Chin, et al, 1992, Potter, et al, 1991). Also Heinz bodies (denatured hemoglobin aggregates) are formed when phosphide concentration in vitro increases to $1.25 \mathrm{ppm}$ (Potter, et al, 1991). Few cases of phosphide poisoning showed intravascular complications as hemolysis and methemoglobinaemia, 
these reactions support the involvement of erythrocytes in the biotransformation of phosphine in vivo in humans (Stewart, et al, 2003).

\section{Clinical features}

Aluminium phosphate poisoning affects the most organs and a variety of signs and symptoms appear in patients. Early symptoms include nausea, vomiting, retrosternal and epigastric pain, dyspnea, anxious, agitation and smell of garlic (Popp, et al, 2002; Aggarwal, et al, 1999; Sood, et al, 1997). on the breath. Moreover shock and peripheral circulatory failure are mainly imperative early signs of toxicity. Mortalities in past studies have ranged from $40-77 \%$ and in one survey 55\% occurred within $12 \mathrm{~h}$ of ingestion and $91 \%$ within $24 \mathrm{~h}$ (Singh, et al, 1991).

\subsection{Cardiac toxicity}

Cardiac toxicity comprises circulatory failure (Alter, et al, 2001) hypotension (Bayazit, et al, 2000; Ragone, et al, 2002), congestion of the heart, separation of myocardial fibres by edema, fragmentation of fibres, non-specifc vacuolation of myocytes, focal necrosis, neutrophil and eosinophil infiltration were found in autopsy (Akkaoui, et al, 2007; Sinha, et al, 2005; Chugh, et al, 1991, Katira, et al, 1990). Also, significantly increasing left ventricular dimensions (Bajaj, et al, 1988), hypokinesia of the left ventricle and septum, akinesia, ejection fractions reduction (Bhasin, et al 1991), severe hypotension, raised systemic venous pressure, normal pulmonary artery wedge pressure, inadequate systemic vasoconstriction and ECG abnormalities (ST and T-wave changes) (Kalra, et al, 1991) are other signs and symptoms.

\subsection{Respiratory toxicity}

Tachypnea, dyspnea, crepitations, and rhonchi were present on examination in 192 out of 418 cases (46\%) of phosphide poisoning (Chugh, et al, 1991) and have been found by others (Gupta, et al, 2000). Pulmonary edema is common but it is not always clear whether it is cardiogenic or non-cardiogenic in etiology. It tends to develop 4-48 $\mathrm{h}$ after ingestion and the finding of a reduced arterial pressure of $\mathrm{O}_{2}$ without an increase in pulmonary artery wedge pressure, suggested it was non-cardiogenic (Kalra, et al, 1991). Others have confidently diagnosed adult respiratory distress syndrome (Singh, et al, 1991, Bajaj, et al, 1988, Gupta, et al, 1995, Chugh, et al 1989) and non-specifed pulmonary edema (Singh, et al, 1996, Chugh, et al, 1998). The edema fluid may be protein-rich and hemorrhagic (Singh, et al, 1996).

\subsection{Gastrointestinal toxicity}

Hematemesis (Gupta, et al, 2000), corrosive lesions of the esophagus and stomach (Madan, et al, 2006, Tiwari, et al, 2003), vomiting, epigastric pain, severe gastric erosions, duodenal erosions, esophageal strictures tracheo-oesophageal fistulae,dysphagia (Darbari, et al, 2007). Dysphagia may be apparent as soon as 3 or 4 days after ingestion of aluminium phosphide (Madan, et al, 2006, Darbari, et al, 2007) but is more usual about 2 weeks later.

\subsection{Hepatic toxicity}

Transient elevations of alanine aminotransferase and aspartate aminotransferase activities are not infrequent after ingestion of metal phosphides (Frangides \& Pneumatikos, 2002; 
Akkaoui, et al, 2007; Bayazit, et al, 2000; Memis, et al, 2007) but jaundice secondary to liver damage (Chugh, et al, 1998) is much less common. It was present in 12 out of 92 cases (Singh, et al, 1991) and was said to be common in another series of 15 patients (Singh, et al, 1985) but confirmatory laboratory data were not provided. Jaundice was alleged to be present in $16(52 \%)$ members of the crew of a grain freighter who inhaled phosphine after an accidental release (Wilson, et al, 1980) but, in the six tested, serum bilirubin concentrations were normal and transaminase activities only minimally disturbed, casting doubt on the clinical observation. Acute hepatic failure and encephalopathy was considered to be the cause of death in one man (Chittora, et al, 1994), while a 12-yearold girl died from a combination of acute hepatic failure and encephalopathy with renal failure (Bayazit, et al, 2000). Portal edema, congestion of the portal tract and central veins, and vacuolization of hepatocytes are the most frequent findings at autopsy (Saleki, et al, 2007).

\subsection{Electrolyte and metabolic abnormalities}

Hypokalemia. metabolic acidosis, mixed metabolic acidosis and respiratory alkalosis, and acute renal failure are reported frequently. Also,Hypoglycemia and hypomagnesemia have been reported in several studies (Chugh, et al, 2000; Dueñas, et al, 1999). Hypokalemia is common soon after ingestion of metal phosphides and is probably secondary to vomiting, though catecholamine release could also contribute. It is thought to be the result of impaired gluconeogenesis and glycogenolysis (Frangides \& Pneumatikos, 2002) possibly secondary to adrenal gland damage and low circulating cortisol concentrations (Chugh, et al, 2000). Hyperglycemia (Abder-Rahman, 1999) appears to be rare. The main controversy relates to the existence or otherwise of disturbances of magnesium homeostasis. In 1989, prompted by reports of the empirical use of magnesium sulphate to treat phosphide toxicity, this study (Singh, et al, 1989; Singh \& Sharma, 1991) demonstrated that serum magnesium concentrations were increased, possibly secondary to release from damaged cardiac myocytes and hepatocytes, and confirmed the findings in subsequent studies (Singh, et al, 1991; Singh, et al, 1990). Unfortunately, other studies have found the converse, that is serum and erythrocyte concentrations were reduced rather than increased. Chugh, et al, (1991) compared serial serum and erythrocyte magnesium concentrations in four groups of people. One comprised patients poisoned with aluminium phosphide who had resulting shock and cardiotoxicity while the second included those poisoned but without shock or cardiac features. The remaining two groups acted as controls, the first being patients in shock secondary to trauma or hemorrhage but without other features of cardiac toxicity and the second, normal volunteers. The only significant finding in admission samples was that cell and serum concentrations were lower in shocked, cardiotoxic patients (mean serum and $\mathrm{RBC}$ concentrations 0.9 and $3.7 \mathrm{mEq} / \mathrm{L}$ respectively compared with 1.8 and $5.2 \mathrm{mEq} / \mathrm{L}$ in volunteers). Since, first, hypomagnesemia was found in toxic shocked patients but not in those with non-toxic shock and secondly, $75 \%$ of those in the toxic/shock group had ECG changes, it was concluded that the evidence supported a causal relationship between hypomagnesemia and phosphide induced shock. Without intervention both serum and cell values returned to normal by about $24 \mathrm{~h}$. The authors confirmed their findings in a later study (Chugh, et al, 1994) and thought the hypomagnesemia secondary to consumption in combating free radical stress (Chugh, et al, 1997). Hypomagnesemia has also been found in a recent single case of phosphine inhalation from aluminium phosphide (Dueñas, et al, 1999). The situation became even more complicated when, in 1994, a study (Siwach, et al, 1994) found themselves unable to agree with either. They found pre-treatment mean serum and 
red cell magnesium concentrations to be normal. Concentrations were increased in the brains, lungs, hearts, livers, kidneys, and stomachs of fatalities but later studies showed this to be the result of magnesium administration and not phosphide toxicity (Siwach, et al, 1995). Clearly, these studies cannot all be correct and the analytical method used to generate the results may be an important factor. The results of a study (Siwach, et al, 1994) carry particular weight because they used atomic absorption spectroscopy, a technique that is superior to the colorimetric method published in 1977 and used (Singh, et al, 1991) and the titan yellow method employed (Chugh, et al, 1991) despite it being claimed that results obtained using the former method correlated extremely well with those from atomic absorption spectroscopy (Khayam-Bashi, et al, 1977). If these studies (Siwach, et al, 1994) are considered the most reliable, there is no choice but to accept that neither hypomagnesemia nor hypermagnesemia is a feature of aluminium phosphide poisoning, though confirmation by another independent study would be welcome.

\subsection{Hematological toxicity}

Although phosphine causes Heinz body formulation and hemoglobin oxidation in vitro (Chin, et al, 1992; Potter, et al, 1991), intravascular hemolysis and methemoglobinaemia are unusual complications of phosphide poisoning in humans. Nine individuals with intravascular hemolysis after ingestion of aluminium phosphide have been identified from the literature. Three were glucose-6-phosphate dehydrogenase deficient (Srinivas, et al, 2007), including one young man who had previously developed haemolysis when given primaquine (Sood, et al, 1997). Two others had no history to suggest this possible predisposing disorder (Aggarwal, et al, 1999; Lakshmi, 2002) and in the remaining four the issue was not addressed (Chugh, et al, 1991). Intravascular hemolysis was associated with renal failure and severe metabolic acidosis to which 3 days of vomiting and diarrhea may have partly contributed (Memis, et al, 2007). In addition to hemolysis one man was found to have methemoglobinaemia of $17 \% 32 \mathrm{~h}$ post-ingestion (Lakshmi, 2002) while another developed Heinz bodies (Srinivas, et al, 2007), a further indicator of damage to hemoglobin. Rats given aluminium phosphide had methemoglobin concentrations measured at 10 and 30 min intervals. They increased simultaneously with those of malonyldialdehyde suggesting that methemoglobinaemia was secondary to increased oxygen free radical generation (Lall, et al, 2000). A study revealed that there is a significant association between blood level of methemoglobin and mortality in patients with aluminium phosphide intoxication (Mostafazadeh, et al, 2010). Disseminated intravascular coagulation was present in six out of 418 patients poisoned with aluminium phosphide (Chugh, et al, 1991).

\subsection{Uncommon features}

Unusual complications of phosphide ingestion include atrial infarction (Jain, et al, 1992), pleural effusion (Bayazit, et al, 2000; Suman \& Savani, 1999), ascites (Bayazit, et al, 2000), skeletal muscle damage (Khosla, et al, 1988), rhabdomyolysis (Abder-Rahman, 1999), a bleeding diathesis (Gupta, et al, 1990), adrenocortical congestion, hemorrhage and necrosis (Arora, et al, 1995), pancreatitis (Sarma, et al, 1996), and renal failure (Chugh, et al, 1991; Singh, et al, 1996; Bayazit, et al, 2000; Gupta, et al, 2000). Acute pericarditis has also been reported infrequently (Wander, et al, 1990; Chugh \& Malhotra, 1992) though pericardial fluid was detected by echocardiography in a third of patients in one study (Bhasin, et al, 1991). Subendocardial infarction complicated the recovery of a 16-year-old male (Kaushik, et al, 2007) and a 26-year-old woman who had recovered from aluminium phosphide ingestion 
suffered an intracranial hemorrhage 5 days after the event. No explanation other than the poison was found (Dave, et al, 1994).

\section{Diagnosis}

A positive history of ingestion is the basis of diagnosis in most cases. The presence of typical clinical features, garlicky odour from the mouth and highly variable arrhythmias in a young patient with shock and no previous history of cardiac disease points towards aluminium phosphide poisoning. Aluminium phosphide poisoning risk is low down in the following instances, When taking patient's history should be special attention to these points:

If the patient uses the expired one

If aluminum phosphide is dissolved in water before use

If the patient experiences immediate vomiting

Confirmation can be done by the Silver Nitrate Test (Chugh, et al, 1989). In this test, $5 \mathrm{ml}$ of gastric aspirate and $15 \mathrm{ml}$ of water are put in a flask and the mouth of the flask is covered by filter paper impregnated with silver nitrate. The flask is heated at $50^{\circ} \mathrm{C}$ for 15 to $20 \mathrm{~min}$. If phosphine is present the filter paper turns black. For performing the test on exhaled air, the silver nitrate impregnated filter paper is placed on the mouth of the patient and the patient is asked to breath through it for 15-20 minutes, blackening of the paper indicates the presence of phosphine in breath. The sensitivity of the test is $100 \%$. However the most specific and sensitive method for detecting the presence of $\mathrm{PH}_{3}$ in blood/air is gas chromatography (Vins Jansen A, Thrane, 1978). For spot sampling of phosphine in air, detector tubes and bulbs are available commercially (International Programme on Chemical Safety, 1998; Leesch, 1982).

\section{Laboratory investigations}

Laboratory evaluation is often performed to assess the prognosis. Leucopenia indicates severe toxicity. Increased aspartate aminotransferase or alanine aminotransferase and metabolic acidosis indicate moderate to severe ingestional poisoning. Electrolyte analysis shows decreased magnesium while potassium may be increased or decreased (Chugh, et al, 1990). Measurement of plasma renin is significant as its level in blood carries a direct relationship with mortality and is raised in direct proportion to the dose of pesticide. The serum level of cortisol is usually found to be decreased in severe poisoning (Chugh, et al, 1989). Chest X-ray may reveal hilar or perihilar congestion if ARDS develops. Electrocardiogram shows various manifestations of cardiac injury (ST depression or elevation, bundle branch block, ventricular tachycardia, ventricular fibrillation) (Jain, et al, 1985; Katira, et al, 1990; Siwach, et al, 1998; Singh, et al, 1989). Wall motion abnormalities, generalised hypokinesia of the left ventricle, decreased ejection fraction and pericardial effusion can be seen in echocardiography (Chugh, 1995).

\section{Prognostic markers}

Development of refractory shock, acute respiratory distress syndrom, aspiration, pneumonitis, anaemia, metabolic acidosis, electrolyte imbalance, coma, severe hypoxia, gastrointestinal bleeding, and pericarditis are associated with poor prognosis. The outcome correlates best with the number of vomiting the patient gets after ingestion and the severity of hypotension the patient develops (Singh, et al, 1998) 95\% of the patients die within 24 
hours and the commonest cause of death in this group is arrhythmia. Death after 24 hours is due to shock, acidosis, acute respiratory distress syndrom and arrhythmia. The mortality rate is highly variable, ranging from $37-100 \%$ and can reach more than $60 \%$ even in experienced and well equipped centres.

\section{Management}

\subsection{Decontamination}

Gastric lavage is probably best avoided after ingestion of phosphides as it might increase the rate of disintegration of the pesticide and increase toxicity (Maitai, et al, 2002). To reduce the absorption of phosphine, gastric lavage with potassium permanganate $(1: 10,000)$ is done. Permanganate is used as it oxidizes $\mathrm{PH}_{3}$ to form non-toxic phosphate. This is followed by a slurry of activated charcoal (approximately $100 \mathrm{gm}$ ) given through a nasogastric tube. In vitro studies suggested that vegetable oil and liquid paraffin inhibit phosphine release from phosphides (Goswami, et al, 1994) but these oils have not been tested in clinical practice. However, vomiting may make the administration of charcoal difficult. Although the administration of sodium bicarbonate via a gastric tube to decrease gastric hydrochloric acid has been proposed in the belief that hydrochloric acid assists the conversion of phosphide to phosphine, there is no experimental support for its use. Moreover, based on an understanding of the mechanisms of toxicity of metal phosphides, this strategy is unlikely to reduce morbidity and mortality. Removal of victims of phosphine inhalation from the contaminated atmosphere will have been carried out by the emergency service first on scene. Supplemental oxygen may be given if necessary but further measures for airway control are unlikely to be required.

\subsection{Supportive care}

Many patients will die from metal phosphide poisoning despite intensive care. Supportive measures are all that can be offered and should be implemented as required by clinical developments. The most important factor for success is resuscitation of shock and institution of supportive measures as soon as possible. Intravenous access should be established and 23 litres of normal saline are administered within the first 8-12 hr guided by central venous pressure (CVP) and pulmonary capillary wedge pressure (PCWP). The aim is to keep the CVP at around 12-14 cm of water (Siwach, et al, 1997). Some workers have recommended rapid infusion of saline (3-6 litres) in the initial $3 \mathrm{hr}$ (Kalra, et al, 1991). Low dose dopamine (4-6 $\mathrm{\mu g} / \mathrm{kg} / \mathrm{min})$ is given to keep systolic blood pressure $>90 \mathrm{~mm} \mathrm{Hg}$. The other vasopressures such as norepinephrine may be usefull in critical patients. The use of high doses of glucagon may benefit in the treatment of aluminum phosphide poisoning; the likely mechanism of action is the increase of cAMP in the myocardium, effectively bypassing the $\beta$-adrenergic second messenger system. Oxygen is given for hypoxia. Acute respiratory distress syndrom requires intensive care monitoring and mechanical ventilation. The blood glucose concentration should be measured in every case and hypoglycemia corrected if found. Similarly, hypokalemia should be sought and, if clinically indicated, at least partially corrected; cardiac features have resolved in occasional patients on correction of potassium concentrations (Kochar, et al, 2000). It must be remembered, however, that the onset of acidosis, renal failure and cell damage may produce life-threatening hyperkalemia. Metabolic acidosis should be managed conventionally. Bicarbonate level less than $15 \mathrm{mEq} / \mathrm{L}$ requires bicarbonate in a dose of 50-100 mEq intravenously every 8 hour (Singh, et al, 1989). 
All types of ventricular arrhythmias are seen in these patients and the management is the same as for arrhythmias in other situations (International Programme on Chemical Safety, 1998).

\subsection{Magnesium supplementation}

The problematic decision is whether or not supplemental magnesium should be given. If magnesium depletion does not occur such a course would appear illogical but single cases have been reported where magnesium administration appeared to terminate atrial fibrillation (Chugh, et al, 1989) and supra ventricular tachycardia and ventricular tachycardia (Chugh, et al, 1991). On the other hand, magnesium sulphate $3 \mathrm{~g}$ given intravenously over $30 \mathrm{~min}$ did not abolish very frequent ventricular ectopic beats and bigeminy though it restored a normal magnesium concentration (Dueñas, et al, 1999). Only a few studies have attempted to assess the value of magnesium sulphate in large groups of patients and their results are conflicting. In a study, 50 patients after aluminium phosphide ingestion were given high doses of magnesium and the result compared with the control group that was not treated. The result showed $(42 \%)$ of those given supplemental magnesium survived compared with $(40 \%)$ not so treated. In addition, treatment did not considerably improve survival at any dose (number of tablets) consumed. As you see magnesium supplementation was of no value in this study (Siwach, et al, 1994). Chugh et al. (2004) obtained opposite results in a case control study. The authors showed survival remarkably improved after each dose ingested for those patients treated by magnesium (Chugh, et al, 2004). To illuminate the potential benefit of magnesium supplementation, additional studies are necessary.

\subsection{N-acetylcysteine}

Different studies in rats (Hsu, et al, 2000, 2002) and humans (Chugh, et al, 1997) showed glutathione concentrations reduction after treating with $\mathrm{N}$-acetylcysteine in patients with aluminium phosphide poisoning (Bogle, et al, 2006).

\subsection{Pralidoxime}

There is experimental and clinical evidence that phosphine (Potter, et al, 1993) and aluminium (Marquis \& Lerrick, 1982, 1983) inhibit acetylcholinesterase. A study (Mittra, et al, 2001) investigated the benefit of administering atropine $1 \mathrm{mg} / \mathrm{kg}$ and pralidoxime 5 $\mathrm{mg} / \mathrm{kg}$ parenterally to rats dosed with aluminium phosphide $10 \mathrm{mg} / \mathrm{kg}(5.55 \times$ LD50) $5 \mathrm{~min}$ previously. Treatment increased the survival time by 2.5-fold in nine out of 15 animals and resulted in the survival of the six remaining animals. There were no survivors in the two control groups. Further studies are required to confirm the benefit of oximes.

\section{Conclusions}

Acute poisoning with metal phosphides, particularly aluminium phosphide, is a worldwide problem most commonly encountered in the Indian Sub-Continent. The clinical features have been well described though it is only recently that the mechanisms of toxicity have been more clearly understood. Poisoning from phosphides is mediated by phosphine which has been shown to rapidly perturb mitochondrial morphology, inhibit oxidative respiration, and cause a severe drop in mitochondrial membrane potential. This failure of cellular 
respiration is likely to be due to a mechanism other than inhibition of cytochrome $\mathrm{C}$ oxidase as phosphine inhibits cytochrome $\mathrm{C}$ oxidase activity less dramatically in vivo than in vitro and only partially inhibits cytochrome $\mathrm{C}$ oxidase activity in humans. Phosphine can also form the highly reactive hydroxyl radical and inhibit both catalase and peroxidase leading to lipid peroxidation. The gas or gases given of in addition to phosphine when phosphide formulations come into contact with water or acid need to be identified and their toxicity determined. The observation that both aluminium and phosphine may inhibit acetylcholinesterase activity needs to be investigated further as does the report that the administration of atropine and pralidoxime reduces morbidity and mortality in aluminium phosphide poisoning. There is conflicting evidence also on the occurrence and clinical importance of magnesium disturbances which some have described. The benefit of magnesium supplementation has still to be determined.

\section{References}

Abder-Rahman H. Effect of aluminium phosphide on blood glucose level. Vet Hum Toxicol 1999; 41:31-32.

Abder-Rahman HA, Battah AH, Ibraheem YM et al. Aluminum phosphide fatalities, new local experience. Med Sci Law 2000; 40:164-168.

Aggarwal P, Handa R, Wig $\mathrm{N}$ et al. Intravascular hemolysis in aluminium phosphide poisoning. Am J Emerg Med 1999; 17:488-489.

Aggarwal P, Handa R, Wig N et al. Intravascular hemolysis in aluminium phosphide poisoning. Am J Emerg Med 1999; 17:488-489.

Akkaoui M, Achour S, Abidi K et al. Reversible myocardial injury associated with aluminum phosphide poisoning. Clin Toxicol 2007; 45:728-731.

Akkaoui M, Achour S, Abidi K et al. Reversible myocardial injury associated with aluminum phosphide poisoning. Clin Toxicol 2007; 45:728-731.

Al-Azzawi MJ, Al-Hakkak ZS, Al-Adhami BW. In vitro inhibitory effects of phosphine on human and mouse serum cholinesterase. Toxicol Environ Chem 1990; 29:53-56.

Alter P, Grimm W, Maisch B. Lethal heart failure caused by aluminium phosphide poisoning. Intensive Care Med 2001; 27:327.

Alter P, Grimm W, Maisch B. Lethal heart failure caused by aluminium phosphide poisoning. Intensive Care Med 2001; 27:327.

Andersen TS, Holm JW, Andersen TS. Forgiftning med muldvarpegasningsmidlet aluminiumfosfid. Ugeskr Laeger 1996; 158:5308-5309.

Anger F, Paysant F, Brousse F et al. Fatal aluminum phosphide poisoning. J Anal Toxicol 2000; 24:90-92.

Arora B, Punia RS, Kalra R et al. Histopathological changes in aluminium phosphide poisoning. J Indian Med Assoc 1995; 93:380-381.

Azoury M, Levin N. Identification of zinc phosphide in a falsely labeled rodenticide bait. J Forensic Sci 1998; 43:693-695.

Bajaj R, Wasir HS, Agarwal R et al. Aluminium phosphide poisoning. Clinical toxicity and outcome in eleven intensively monitored patients. Natl Med J India 1988; 1:270-274.

Bajaj R, Wasir HS, Agarwal R et al. Aluminium phosphide poisoning. Clinical toxicity and outcome in eleven intensively monitored patients. Natl Med J India 1988; 1:270-274.

Bayazit AK, Noyan A, Anarat A. A child with hepatic and renal failure caused by aluminum phosphide. Nephron 2000; 86:517. 
Bayazit AK, Noyan A, Anarat A. A child with hepatic and renal failure caused by aluminum phosphide. Nephron 2000; 86:517.

Bhasin P, Mittal HS, Mitra A. An echocardiographic study in aluminium phosphide poisoning. J Assoc Physicians India 1991; 39:851.

Bogle RG, Theron P, Brooks P et al. Aluminium phosphide poisoning. Emerg Med J 2006; 23:e3.

Bogle RG, Theron P, Brooks P et al. Aluminium phosphide poisoning. Emerg Med J 2006; 23:e3.

Bolter CJ, Chertuka W. Extra-mitochondrial release of $\mathrm{H} 2 \mathrm{O} 2$ from insect, mouse liver mitochondria using respiratory inhibitor phosphine, myxothiazole and antimycin and special analysis of inhibited cytochromes. Arch Biochem Biophy 1989; 278: 73.

Brautbar N, Howard J. Phosphine toxicity: report of two cases and review of the literature. Toxicol Ind Health 2002; 18:71-75.

Broderick M, Birnbaum K. Fatal ingestion of zinc phosphide rodenticide. J Toxicol Clin Toxicol 2002; 40:684.

Burgess JL. Phosphine exposure from a methamphetamine laboratory investigation. J Toxicol Clin Toxicol 2001; 39:165-168.

Chan LT, Crowley RJ, Delliou D, Geyer R. Phosphine analysis in post mortem specimens following ingestion of aluminium phosphide. J Anal Toxicol 1983; 7:165-167.

Chaudhry MQ. A review of the mechanisms involved in the action of phosphine as an insecticide and phosphine resistance in stored-product insects. Pestic Sci 1997; 49:213 228.

Chin KL, Mai X, Meaklim J et al. The interaction of phosphine with haemoglobin and erythrocytes. Xenobiotica 1992; 22:599-607.

Chin KL, Mai X, Meaklim J et al. The interaction of phosphine with haemoglobin and erythrocytes. Xenobiotica 1992; 22:599-607.

Chittora MD, Meena SR, Gupta DK, Bhargava S. Acute hepatic failure in aluminium phosphide poisoning. J Assoc Physicians India 1994; 42:924.

Chittora MD, Meena SR, Gupta DK, Bhargava S. Acute hepatic failure in aluminium phosphide poisoning. J Assoc Physicians India 1994; 42:924.

Chug SN, Arora V, Sharma A, Chug K. Free radical scavengers and lipid peroxidation in acute aluminium phosphide poisoning. IJMR 1996; 104: 190.

Chugh SN, Aggarwal HK, Mahajan SK. Zinc phosphide intoxication symptoms: analysis of 20 cases. Int J Clin Pharmacol Ther 1998; 36:406-407.

Chugh SN, Chugh K, Ram S, Malhotra KC. Electrocardiographic abnormalities in aluminium phosphide poisoning with special reference to its incidence, pathogenesis, mortality and histopathology. J Indian Med Assoc 1991; 89:32-35.

Chugh SN, Dushyant, Ram S et al. Incidence \& outcome of aluminium phosphide poisoning in a hospital study. Indian J Med Res 1991; 94:232-235.

Chugh SN, Jaggal KL, Ram S et al. Hypomagnesaemic atrial fibrillation in a case of aluminium phosphide poisoning. J Assoc Physicians India 1989; 37:548-549.

Chugh SN, Jaggal KL, Sharma A et al. Magnesium levels in acute cardiotoxicity due to aluminium phosphide poisoning. Indian J Med Res 1991; 94:437-439.

Chugh SN, Juggal KL, Sharma A, Arora B, Malhotra KC. Magnesium levels in aluminium phosphide poisoning [Abstract]. J Assoc Physicians India 1990; 38:32.

Chugh SN, Kishore K, Aggarwal N, Attri S. Hypoglycaemia in acute aluminium phosphide poisoning. J Assoc Physicians India 2000; 48:855-856. 
Chugh SN, Kolley T, Kakkar R et al. A critical evaluation of antiperoxidant effect of intravenous magnesium in acute aluminium phosphide poisoning. Magnes Res 1997; 10:225-230.

Chugh SN, Kolley T, Kakkar R et al. A critical evaluation of antiperoxidant effect of intravenous magnesium in acute aluminium phosphide poisoning. Magnes Res 1997; 10:225- 230.

Chugh SN, Kumar P, Sharma A et al. Magnesium status and parenteral magnesium sulphate therapy in acute aluminium phosphide intoxication. Magnes Res 1994; 7:289-294.

Chugh SN, Malhotra KC. Acute pericarditis in aluminium phosphide poisoning. J Assoc Physicians India 1992; 40:564.

Chugh SN, Malhotra S, Kumar P, Malhotra KC. Reversion of ventricular and supraventricular tachycardia by magnesium sulphate therapy in aluminium phosphide poisoning. Report of two cases. J Assoc Physicians India 1991; 39:642-643.

Chugh SN, Ram S, Chugh K, Malhotra KC. Spot diagnosis of aluminium phosphide ingestion: an application of a simple test. J Assoc Physicians India 1989;37(3):219-20.

Chugh SN, Ram S, Mehta LK et al. Adult respiratory distress syndrome following aluminium phosphide ingestion. Report of 4 cases. J Assoc Physicians India 1989; 37:271-272.

Chugh SN, Ram S, Sharma A, Arora BB, Saini AS, Malhotra KC. Adrenocortical involvement in aluminium phosphide poisoning. Indian J Med Res 1989;90:289-94.

Chugh SN. Aluminium phosphide poisoning with special reference on its diagnosis and management[Review article]. J Med Assoc Clin Med 1995:1:20-2.

Curcic M, Dadasovic J. Pokusana I izvrsena samoubistva rodenticidima od 1968 do 2000 godine. Med Pregl 2001; 54:256-260.

Darbari A, Kumar A, Chandra G, Tandon S. Tracheo-oesophageal fistula with oesophageal stricture due to aluminium phosphide (Celphos tablet) poisoning. J Chest Dis Allied Sci 2007; 49:241-242.

Dave HH, Dave TH, Rakholia VG et al. Delayed hemorrhagic stroke following accidental aluminium phosphide ingestion. J Assoc Physicians India 1994; 42:78-79.

Dueñas A, Pérez-Castrillon JL, Cobos MA, Herreros V. Treatment of the cardiovascular manifestations of phosphine poisoning with trimetazidine, a new antiischemic drug. Am J Emerg Med 1999; 17:219-220.

Dueñas A, Pérez-Castrillon JL, Cobos MA, Herreros V. Treatment of the cardiovascular manifestations of phosphine poisoning with trimetazidine, a new antiischemic drug. Am J Emerg Med 1999; 17:219-220.

Dumas T, Bond EJ. Separation of phosphine from odour-producing impurities. J Stored Prod Res 1974; 10:67-68.

Eddleston M, Phillips MR. Self poisoning with pesticides. BMJ 2004;328:42-44.

Fluck E. The odor threshold of phosphine. J Air Pollut Control Assoc 1976; 26:795.

Frangides CY, Pneumatikos IA. Persistent severe hypoglycemia in acute zinc phosphide poisoning. Intensive Care Med 2002; 28:223.

Gargi J, Rai H, Chanana A et al. Current trend of poisoning - a hospital profile. J Indian Med Assoc 2006; 104:72-73, 94.

Glass A. Account of suspected phosphine poisoning in a submarine. J R Nav Med Serv 1959; 42:184-187.

Goswami M, Bindal M, Sen P et al. Fat and oil inhibit phosphine release from aluminium phosphide - its clinical implication. Indian J Exp Biol 1994; 32:647-649.

Gregorakos L, Sakayianni K, Harizopoulou V. Recovery from severe inhalational phosphine poisoning. Report of two cases. Clin Intensive Care 2002; 13:177-179. 
Gupta MS, Malik A, Sharma VK. Cardiovascular manifestations in aluminium phosphide poisoning with special reference to echocardiographic changes. J Assoc Physicians India 1995; 43:773-774, 779-780.

Gupta MS, Mehta L, Chugh SN, Malhotra KC. Aluminium phosphide poisoning. Two cases with rare presentation. J Assoc Physicians India 1990; 38:509-510.

Gupta SK, Peshin SS, Srivastava A, Kaleekal T. A study of childhood poisoning at National Poisons Information Centre, All India Institute of Medical Sciences, New Delhi. J Occup Health 2003; 45:191-196.

Gupta V, Singh J, Doodan SS, Bali SK. Multisystem organ failure (MSOF) in aluminium phosphide (ALP) poisoning. JK Pract 2000; 7:287-288.

Hackenberg U. Chronic ingestion by rats of standard diet treated with aluminum phosphide. Toxicol Appl Pharmacol 1972;23(1):147-58.

Hajouji Idrissi M, Oualili L, Abidi K et al. Facteurs de gravité de l'intoxication aiguë au phosphure d'aluminium (Phostoxin $\left.{ }^{\circledR}\right)$. Ann Fr Anesth Réanim 2006; 25:382-385.

Hansen HL, Pedersen G. Poisoning at sea: injuries caused by chemicals aboard Danish merchant ships 1988-1996. J Toxicol Clin Toxicol 2001; 39:21-26.

Heyndrickx A, Van Peteghem C, Van Den Heede M, Lauwaert R.Double fatality with children due to fumigated wheat. Eur J Toxicol 1976; 9:113-118.

Hsu C-H, Chi B-C, Liu M-Y et al. Phosphine-induced oxidative damage in rats: role of glutathione. Toxicology 2002; 179:1-8.

Hsu C-H, Han B-C, Liu M-Y et al. Phosphine-induced oxidative damage in rats: attenuation by melatonin. Free Radic Biol Med 2000; 28:636-642.

Idali B, Miguil M, Moutawakkil S et al. Intoxication aiguë au phostoxin. Presse Med 1995; 24:611-612.

International Programme on Chemical Safety. Environmental health criteria 73: phosphine and selected metal phosphides. Geneva: World Health Organization; 1998. [cited 2007 Sep 14]. Available from: http://www.who.int/ipcs/publications.

IPCS. Environmental health criteria 73. Phosphine and selected metal phosphides. Geneva: World Health Organization, 1988.

Jain MK, Khanijo SK, Pathak N et al. Electrocardiographic diagnosis of atrial infarction in aluminium phosphide poisoning. J Assoc Physicians India 1992; 40:692-693.

Jain SM, Bharani A, Sepaha GC, Sanghvi VC, Raman PG. Electrocardiographic changes in aluminium phosphide (ALP) poisoning [Case reports]. J Assoc Physicians India 1985;33(6):406-9.

Jeyaratnam J. Acute pesticide poisoning: A major global health problem. World Health Stat Q 1990; 43:139-144.

Kalra GS, Anand IS, Jit I et al. Aluminium phosphide poisoning: haemodynamic observations. Indian Heart J 1991; 43:175-178.

Kalra GS, Anand IS, Jit I, Bushnurmath B, Wahi PL. Aluminium phosphide poisoning: haemodynamic observations. Indian Heart J 1991;43(3):175-8.

Kamanyire R, Murray V. Occupational exposures to fumigants. J Toxicol Clin Toxicol 2003; 41:489-490.

Katira R, Elhence GP, Mehrotra ML et al. A study of aluminium phosphide (Aluminium phosphide poisoning) poisoning with special reference to electrocardiographic changes. J Assoc Physicians India 1990; 38: 471-473.

Katira R, Elhence GP, Mehrotra ML, Srivastava SS, Mitra A, Agarwala R, et al. A study of aluminum phosphide (AIP) poisoning with special reference to electrocardiographic changes. J Assoc Physicians India 1990;38(7):471-3. 
Kaushik RM, Kaushik R, Mahajan SK. Subendocardial infarction in a young survivor of aluminium phosphide poisoning. Hum Exp Toxicol 2007; 26:457-460.

Khayam-Bashi H, Liu TZ, Walter V. Measurement of serum magnesium with a centrifugal analyzer. Clin Chem 1977; 23:289-291.

Khosla SN, Nand N, Khosla P. Aluminium phosphide poisoning. J Trop Med Hyg 1988; 91:196-198.

Kochar DK, Shubhakaran, Jain N et al. Successful management of hypokalaemia related conduction disturbances in acute aluminium phosphide poisoning. J Indian Med Assoc 2000; 98:461-462.

Lakshmi B. Methemoglobinemia with aluminum phosphide poisoning. Am J Emerg Med 2002; 20:130-132.

Lall SB, Peshin SS, Mitra S. Methemoglobinemia in aluminium phosphide poisoning in rats. Indian J Exp Biol 2000; 38:95-97.

Lauterbach M, Solak E, Kaes J et al. Epidemiology of hydrogen phosphide exposures in humans reported to the Poison Center in Mainz,Germany, 1983-2003. Clin Toxicol 2005; 43:575-581.

Lawler JM, Thomas SHL. "Off gassing" following fatal aluminium phosphide ingestion. Clin Toxicol 2007; 45:362.

Leesch JG. Accuracy of different sampling pumps and detector tube combinations to determine phosphine concentration. J Econ Entomol 1982;75:899-905.

Lohani SP, Casavant MJ, Ekins BR et al. Zinc phosphide poisoning: a retrospective study of 21 cases. J Toxicol Clin Toxicol 2000; 38:515.

Madan K, Chalamalasetty SB, Sharma M, Makharia G. Corrosive-like strictures caused by ingestion of aluminium phosphide. Natl Med J India 2006; 19:313-314.

Maitai CK, Njoroge DK, Abuga KO et al. Investigation of possible antidotal effects of activated charcoal, sodium bicarbonate, hydrogen peroxide and potassium permanganate in zinc phosphide poisoning. East Central Afr J Pharm Sci 2002; 5:38-41.

Marquis JK, Lerrick AJ. Noncompetitive inhibition by aluminum, scandium and yttrium of acetylcholinesterase from Electrophorus electricus. Biochem Pharmacol 1982;

Marquis JK. Aluminum inhibition of human serum cholinesterase. Bull Environ Contam Toxicol 1983; 31:164-169.

Memis D, Tokatlioglu D, Koyuncu O, Hekimoglu S. Fatal aluminium phosphide poisoning. Eur J Anaesthesiol 2007; 24:292-293.

Misra UK, Bhargava AK, Nag D et al. Occupational phosphine exposure in Indian workers. Toxicol Lett 1988; 42:257-263.

Mittra S, Peshin SS, Lall SB. Cholinesterase inhibition by aluminium phosphide poisoning in rats and effects of atropine and pralidoxime chloride. Acta Pharmacol Sin 2001; 22:37-39.

Mostafazadeh B, Pajoumand A, Farzaneh E, et al. Blood Levels of Methemoglobin in Patients with Aluminum Phosphide Poisoning and its Correlation with Patient's Outcome. J. Med. Toxicol. 2011; 7:40-43.

Nocera A, Levitin HW, Hilton JMN. Dangerous bodies: a case of fatal aluminium phosphide poisoning. Med J Aust 2000; 173:133-135.

Pajoumand A, Jalali N, Abdollahi M, Shadnia S. Survival following severe aluminium phosphide poisoning. J Pharm Pract Res 2002; 32:297-299.

Patial RK, Bansal SK, Kashyap S et al. Hypoglycaemia following zinc phosphide poisoning. J Assoc Physicians India 1990; 38:306-307.

Pepelko B, Seckar J, Harp PR et al. Worker exposure standard for phosphine gas. Risk Anal 2004; 24:1201-1213. 
Popp W, Mentfewitz J, Gotz R, Voshaar T. Phosphine poisoning in a German office. Lancet 2002; 359:1574.

Popp W, Mentfewitz J, Gotz R, Voshaar T. Phosphine poisoning in a German office. Lancet 2002; 359:1574.

Potter WT, Garry VF, Kelly JT et al. Radiometric assay of red cell and plasma cholinesterase in pesticide appliers from Minnesota. ToxicolAppl Pharmacol 1993; 119:150-155.

Potter WT, Garry VF, Kelly JT et al. Radiometric assay of red cell and plasma cholinesterase in pesticide appliers from Minnesota. Toxicol Appl Pharmacol 1993; 119:150155.31:1437-1440.

Potter WT, Rong S, Griffith J et al. Phosphine-mediated Heinz body formation and hemoglobin oxidation in human erythrocytes. Toxicol Lett 1991; 57:37-45.

Potter WT, Rong S, Griffith J et al. Phosphine-mediated Heinz body formation and hemoglobin oxidation in human erythrocytes. Toxicol Lett 1991; 57:37-45.

Price NR, Moles KA, Hamphires OA. Phosphine toxicity and catalase activity in susceptible and resistant strains of lesser grain borer. Comp Biochem Physiol 1982; 73: 411 415.

Ragone S, Bernstein J, Lew E, Weisman R. Fatal aluminum phosphide ingestion. J Toxicol Clin Toxicol 2002; 40:690.

Ragone S, Bernstein J, Lew E, Weisman R. Fatal aluminum phosphide ingestion. J Toxicol Clin Toxicol 2002; 40:690.

Rastogi P, Raman R, Rastogi VK. Serum cholinesterase and brain acetylcholinesterase activity in aluminium phosphide binding. Med Sci Res 1990; 18:783-784.

Rimalis BT, Bochkarnikov VV. [Acute hepatorenal insufficiency in some rare acute exogenous poisoning.]. Klin Med 1978; 56:125-128.

Roberts DM, Ranganath H, Buckley NA. Acute intentional self-poisoning with zinc phosphide. Clin Toxicol 2006; 44:465-466.

Saleki S, Ardalan FA, Javidan-Nejad A. Liver histopathology of fatal phosphine poisoning. Forensic Sci Int 2007; 166:190-193.

Sarma PSA, Narula J. Acute pancreatitis due to zinc phosphide ingestion. Postgrad Med J 1996; 72:237-238.

Singh RB, Rastogi SS, Singh DS. Cardiovascular manifestations of aluminium phosphide intoxication. J Assoc Physicians India 1989; 37:590-592.

Singh RB, Saharia RB, Sharma VK. Can aluminium phosphide poisoning cause hypermagnesaemia? A study of 121 patients. Magnes Trace Elem 1990; 9:212-218.

Singh RB, Singh RG, Singh U. Hypermagnesemia following aluminum phosphide poisoning. Int J Clin Pharmacol Ther Toxicol 1991; 29:82-85.

Singh RB, Singh RG, Singh U. Hypermagnesemia following aluminum phosphide poisoning. Int J Clin Pharmacol Ther Toxicol 1991; 29:82-85.

Singh S, Dilwari JB, Vashist R et al. Aluminium phosphide ingestion. Br Med J 1985; 290:1110-1111.

Singh S, Sharma BK. Aluminium phosphide poisoning. J Assoc Physicians India 1991; 39:423-424.

Singh S, Singh D, Wig N et al. Aluminum phosphide ingestion - A clinicopathologic study. J Toxicol Clin Toxicol 1996; 34:703-706.

Singh S, Singh D, Wig N, Jit I, Sharma BK. Aluminum phosphide ingestion - a clinicopathologic study. J Toxicol Clin Toxicol 1996;34(6):703-6.

Sinha US, Kapoor AK, Singh AK et al. Histopathological changes in cases of aluminium phosphide poisoning. Indian J Pathol Microbiol 2005; 48:177-180. 
Siwach SB, Dua A, Sharma R et al. Tissue magnesium content and histopathological changes in non-survivors of aluminium phosphide poisoning. J Assoc Physicians India 1995; 43:676-678.

Siwach SB, Gupta A. The profile of acute poisonings in Harayana- Rohtak study. J Assoc Physicians India 1995; 43:756-759.

Siwach SB, Jagdish, Katyal VK, Dhall A, Bhardwaj G. Prognostic indices in aluminium phosphide poisoning observations on acidosis \& central venous pressure. J Assoc Physicians India 1997;45:693-5.

Siwach SB, Singh H, Jagdish, Katyal VK, Bhardwaj G. Cardiac arrhythmias in aluminium phosphide poisoning studied by on continuous holter and cardioscopic monitoring. J Assoc Physicians India 1998;46(7):598-601.

Siwach SB, Singh P, Ahlawat $S$ et al. Serum and tissue magnesium content in patients of aluminium phosphide poisoning and critical evaluation of high dose magnesium sulphate therapy in reducing mortality. J Assoc Physicians India 1994; 42: 107-110.

Siwach SB, Singh P, Ahlawat S et al. Serum and tissue magnesium content in patients of aluminium phosphide poisoning and critical evaluation of high dose magnesium sulphate therapy in reducing mortality. J Assoc Physicians India 1994; 42:107-110.

Siwach SB, Singh P, Ahlawat S. Magnesium in aluminium phosphide poisoning - where have we erred? J Assoc Physicians India 1994; 42:193-194.

Sood AK, Mahajan A, Dua A. Intravascular haemolysis after aluminium phosphide ingestion. J R Soc Med 1997; 90:47-48.

Sood AK, Mahajan A, Dua A. Intravascular haemolysis after aluminium phosphide ingestion. J R Soc Med 1997; 90:47-48.

Stewart A, Whiteside C, Tyler-Jones C et al. Phosphine suicide. Chemical Incident Rep 2003; 27:23-26.

Stewart A, Whiteside C, Tyler-Jones C et al. Phosphine suicide. Chemical Incident Rep 2003; 27:23-26.

Sudakin DL. Occupational exposure to aluminium phosphide and phosphine gas? A suspected case report and review of the literature. Hum Exp Toxicol 2005; 24:27

Suman RL, Savani M. Pleural effusion - a rare complication of aluminium phosphide poisoning. Indian Pediatr 1999; 36:1161-1163.

Tiwari J, Lahoti B, Dubey K et al. Tracheo-oesophageal fistula - an unusual complication following celphos poisoning. Indian J Surg 2003; 65:442-444.

Vins Jansen A, Thrane KE. Gas chromatographic determination of $\mathrm{PH} 3$ in ambient air. Analysis 1978; 103:1195-8.

Vohra RB, Schwarz KA, Williams SR, Clark RF. Phosphine toxicity with echocardiographic signs in railcar stowaways. Clin Toxicol 2006; 44:719-720.

Wander GS, Arora S, Khurana SB. Acute pericarditis in aluminium phosphide poisoning. J Assoc Physicians India 1990; 38:675.

Willers-Russo LJ. Three fatalities involving phosphine gas, produced as a result of methamphetamine manufacturing. J Forensic Sci 1999; 44:647-652.

Wilson R, Lovejoy FH, Jr., Jaeger RJ, Landrigan PL. Acute phosphine poisoning aboard a grain freighter: epidemiologic, clinical and pathological findings. JAMA 1980; 244:148-150.

Wilson R, Lovejoy FH, Jr., Jaeger RJ, Landrigan PL. Acute phosphine poisoning aboard a grain freighter: epidemiologic, clinical and pathological findings. JAMA 1980; 244:148-150. 


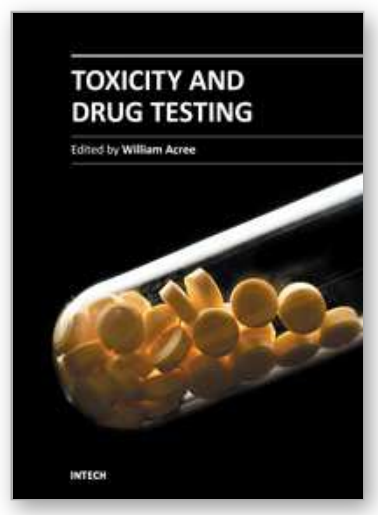

\author{
Toxicity and Drug Testing \\ Edited by Prof. Bill Acree
}

ISBN 978-953-51-0004-1

Hard cover, 528 pages

Publisher InTech

Published online 10, February, 2012

Published in print edition February, 2012

Modern drug design and testing involves experimental in vivo and in vitro measurement of the drug candidate's ADMET (adsorption, distribution, metabolism, elimination and toxicity) properties in the early stages of drug discovery. Only a small percentage of the proposed drug candidates receive government approval and reach the market place. Unfavorable pharmacokinetic properties, poor bioavailability and efficacy, low solubility, adverse side effects and toxicity concerns account for many of the drug failures encountered in the pharmaceutical industry. Authors from several countries have contributed chapters detailing regulatory policies, pharmaceutical concerns and clinical practices in their respective countries with the expectation that the open exchange of scientific results and ideas presented in this book will lead to improved pharmaceutical products.

\title{
How to reference
}

In order to correctly reference this scholarly work, feel free to copy and paste the following:

Babak Mostafazadeh (2012). Aluminium Phosphide Poisoning, Toxicity and Drug Testing, Prof. Bill Acree (Ed.), ISBN: 978-953-51-0004-1, InTech, Available from: http://www.intechopen.com/books/toxicity-and-drugtesting/aluminium-phosphide-poisoning

\section{INTECH}

open science | open minds

\section{InTech Europe}

University Campus STeP Ri

Slavka Krautzeka 83/A

51000 Rijeka, Croatia

Phone: +385 (51) 770447

Fax: +385 (51) 686166

www.intechopen.com

\section{InTech China}

Unit 405, Office Block, Hotel Equatorial Shanghai

No.65, Yan An Road (West), Shanghai, 200040, China

中国上海市延安西路65号上海国际贵都大饭店办公楼 405 单元

Phone: +86-21-62489820

Fax: $+86-21-62489821$ 
(C) 2012 The Author(s). Licensee IntechOpen. This is an open access article distributed under the terms of the Creative Commons Attribution 3.0 License, which permits unrestricted use, distribution, and reproduction in any medium, provided the original work is properly cited. 